\title{
Gender, Social Capital and Information Exchange in Rural Uganda
}

\author{
Enid Katungi, University of Pretoria \\ Svetlana Edmeades, International Food Policy Research Institute \\ and \\ Melinda Smale, International Food Policy Research Institute
}

The CGIAR Systemwide Program on Collective Action and Property Rights (CAPRi) is an initiative of the 15 centers that belong to the Consultative Group on International Agricultural Research. The initiative promotes comparative research on the role played by property rights and collective action institutions in shaping the efficiency, sustainability, and equity of natural resource systems. CAPRi's Secretariat is hosted by the International Food Policy Research Institute's (IFPRI) Environment and Production Technology Division (www.ifpri.org.

CAPRi Working Papers contain preliminary material and research results and are circulated prior to a full peer review in order to stimulate discussion and critical comment. It is expected that most Working Papers will eventually be published in some other form, and that their content may also be revised.

Copyright $\odot$ December 5, 2006 International Food Policy Research Institute. All rights reserved. Sections of this material may be reproduced for personal and not-for-profit use without the express written permission of but with acknowledgment to IFPRI. To reproduce the material contained herein for profit or commercial use requires express written permission. To obtain permission to reprint, contact the IFPRI Communications Division at ifpri-copyright@cgiar.org.

CGIAR Systemwide Program on Collective Action and Property Rights (CAPRi) c/O INTERNATIONAL FOOD POLICY RESEARCH INSTITUTE 


\begin{abstract}
Changing agricultural research and extension systems mean that informal mechanisms of information diffusion are often the primary source of information about improved seed and practices for farmers in sub-Saharan Africa. This paper investigates the interactions between gender, social capital and information exchange in rural Uganda. Within the framework of farmer-to-farmer models, we conceptualize the informal information diffusion process to comprise social capital accumulation and information exchange. We assume that each agent participates in information exchange with a fixed (predetermined) level of social capital and examine how endowments of social capital influence information exchange, paying close attention to gender differences. A multinomial logit model is used to analyze multiple participation choices of information exchange facing the farmer. Findings demonstrate that social capital is an important factor in information exchange, with men generally having better access to social capital than women. We also find strong evidence in support of group-based technology dissemination systems.
\end{abstract}

Keywords: gender; social capital; information exchange; informal mechanisms; Uganda 


\section{TABLE OF CONTENTS}

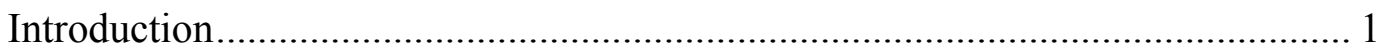

Gender, Social Capital, Information Exchange ................................................ 4

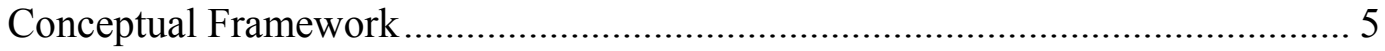

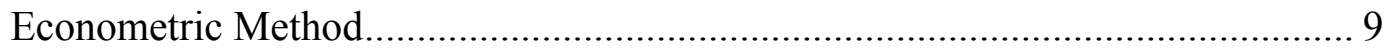

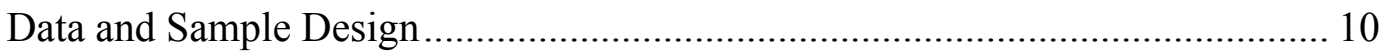

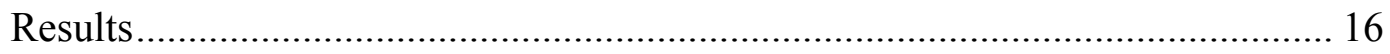

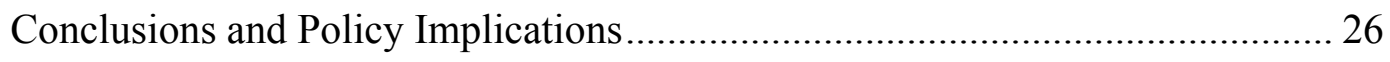

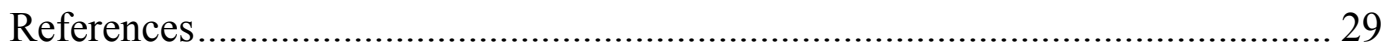




\title{
Gender, Social Capital and Information Exchange in Rural Uganda
}

\author{
Enid Katungi, ${ }^{1}$ Svetlana Edmeades, ${ }^{2}$ and Melinda Smale ${ }^{3}$
}

\section{INTRODUCTION}

In light of growing challenges of population pressure, land degradation, and declining agricultural productivity, farming in sub-Saharan Africa is increasingly knowledge intensive.

Agricultural households deal with different biotic pressures simultaneously (e.g., pest and disease infestations, drought, soil fertility) while trying to compete in the global market for their produce.

Small-scale producers often rely on informal mechanisms of information exchange and knowledge sharing to address these challenges. Given the limited scope of formal extension programs, informal exchange is often the primary source of information about new technologies in sub-Saharan Africa.

The increasing role of informal mechanisms for information sharing has been recognized in the literature through farmer-to-farmer models of agricultural development (Eveleens et al. 1996). Unlike the traditional extension model, which treats farmers as passive recipients of information, the farmer-to-farmer model recognizes that farmers actively gather information from fellow farmers to enhance their knowledge. This process of information gathering, or social

1 Doctoral student at the University of Pretoria, South Africa and Researcher at the Banana Program of the National Agricultural Research Organization (NARO), Uganda

2 * Postdoctoral Fellow (Corresponding Author), Environment and Production Technology Division (EPTD), International Food Policy Research Institute (IFPRI), Washington D.C.

3 Senior Research Fellow, Environment and Production Technology Division (EPTD), International Food Policy Research Institute (IFPRI), Washington D.C. 
learning, is characterized by pooling of information or observing the behavior of others and imitating it.

Although the role of social learning in technology adoption is well recognized in the literature (Foster and Rosenzweig 1995; Conley and Udry 2001; Munshi 2004), factors that intervene in the process are less known. A common assumption in previous research has been that information from early adopters is freely available in the village and all potential adopters can equally access it (Conley and Udry 2001). Differences in social learning have typically been attributed to endogenous factors, such as risk preferences, human capital and attitudes (Kislev and Shchori-Bachrach 1973; Hiebert 1974; Feder and Slade 1984). Social capital is increasingly recognized as an intervening factor in the process of social learning and information exchange. Social capital depicts the features of social organizations, such as social institutions, networks or associations, less institutionalized networks of friends, relatives and acquaintances (or private social networks) and civic engagement, that enable knowledge gathering and information exchange.

Social capital may influence social learning and information diffusion in a number of ways. First, social capital reduces the cost of information acquisition since it can be acquired passively during social interactions or actively from people who already know each other. Second, social capital reduces the uncertainty about the reliability of information. Information is likely to be given a higher value if it comes from trusted people. Third, social capital facilitates the willingness and cooperation to share information, thereby revealing the tacit information that would be difficult to exchange otherwise (Yli Renko et al. 2002).

Research documenting the role of social capital on information flows in developing economies has been growing. Limited attention has been given to gender aspects that may influence both social learning processes and accumulation of social capital. Emerging empirical evidence provides support for the role of gender in information exchange through different, 
gender-related stocks of information and usage of social capital (Maluccio et al. 2003). In many rural areas, where small-scale agriculture takes place, gender differences have been found to have a significant impact on resource allocation and productivity in agriculture (Alderman et al. 2003).

This paper contributes to the literature by providing evidence of gender disparities in the access and exchange of information in rural Uganda. We hypothesize that there are gender differences in information exchange that can be attributed to gender differences in the formation and use of social capital among agricultural households. The information exchanged pertains to different agricultural technologies for improving the productivity of bananas, the staple crop of Uganda.

A multinomial logit is used to estimate the response probabilities associated with participation in informal information exchange related to new agricultural technologies in rural Uganda. Participation takes the form of receiving or sending information, or both. Participation in information exchange is estimated for the full sample, while controlling for gender, as well as for two sub-samples (male- and female-headed households) in order to capture gender differences in social capital formation and in the reciprocity of information exchange.

Section two contains a brief overview of the literature on interactions between gender, social capital formation and diffusion of information. Section three develops a conceptual framework of information exchange among rural households, focusing on the role of social capital in the process. This section also lays out the theoretical model of household participation in information exchange. The empirical model is described in section four, followed by description of the data and variables used in the analysis. The results section provides a description of the contextual background of rural households in Uganda, as well as the empirical findings of the study. The paper concludes with a discussion of the implications for policy drawn from the analysis. 


\section{GENDER, SOCIAL CAPITAL, INFORMATION EXCHANGE}

Development programs are often criticized for failing to account for gender inequalities in decisionmaking, task allocation and resource ownership and management, which has implications for policy recommendations (Quisumbing 2003). Gender inequalities almost always favor men, with women often being disadvantaged both in the control over household assets (Fafchamps and Quisumbing 2003) and in the division of responsibilities in the household and in the community. Even when a woman heads the household and is in charge of household resources, gender differences emerge across female-headed households and their male-headed counterparts. Significant heterogeneity among female-headed households has also been highlighted in the literature implying differential provision of resources and their use among rural settings (Peters 1983). Women and men also have different resource endowments when pursuing livelihood strategies, which could have far-reaching consequences on social capital formation and information exchange.

To build and maintain a social network is costly in terms of both time and other resources (Dasgupta 2005), imposing a barrier to social capital accumulation (Ioannides and Loury 2004). Women typically have a high opportunity cost of time that reduces their incentives to participate in certain social networks (Meinzen-Dick and Zwarteveen 2003). Women have been found to join groups that mobilize fewer resources than men because they are resource-constrained (Maluccio et al 2003). Gender norms in the community may also exclude women from social capitalenhancing activities, such as drinking clubs. Meinzen-Dick and Zwarteveen (2003) demonstrate how barriers faced by women in their participation in water management user groups in South Asia may stimulate use of alternative forms of social capital such as a network of friends and relatives. Different social networks may provide different or unequal services to their members that could exacerbate women's disadvantages in development. 
If women and men have different types and qualities of social capital, they may participate differently in information exchange. Men may be inclined to acquire and provide more information to their social network (i.e. pooling of information) than women. Women are often more dependent on informal networks based on everyday forms of collaboration, such as collecting water, fetching fuel wood and rearing children. These services, together with the fact that women have a high opportunity cost of time, may motivate women to form networks with individuals who are geographically close to reduce the length of time required for travel for social interaction. However, geographically close networks tend to be limited in their scope of information transmission (Granovetter 1973). In contrast, men may be engaged in more geographically dispersed social networks, such as community projects, and may participate more in civic engagement (Maluccio et al. 2003). Such participation provides them with greater access to information and stimulates information exchange with others (Granovetter 1973).

If women and men belong to the same social networks, but men take on brokerage positions (i.e. bridge otherwise disconnected social groups), then new information obtained by men from distant social networks may quickly diffuse to women. Though provided with access to social information, women become net information receivers and disproportionately underparticipate as information providers. Therefore, gender differences may emerge in the extent of reciprocity of information exchange.

\section{CONCEPTUAL FRAMEWORK}

Previous studies on information acquisition in agriculture conceptualize farmers as merely information consumers who choose sources of information that will maximize their expected utility (Just et al. 2002; Wozniak 1993, Feder and Slade 1984). Models employed to analyze the determinants of information acquisition were to a large extent biased towards formal sources of information (i.e. specialized information providers such as extension educators, radios 
or publications). Information from other farmers was assumed to be freely available to all farmers (Feder and Slade 1984).

Starting with the work of Conley and Udry (2001) this assumption has been challenged. It is now increasingly recognized that information on agricultural innovations diffuses through social networks rather than being freely available in the village. We adhere to this view in studying the role that social capital may play in facilitating information exchange among rural households in Uganda. We further differentiate the social networks by gender in order to gain greater insight into how gender inequalities influence the effectiveness of social capital in facilitating information exchange.

Information from other farmers diffuses through pooling and copying mechanisms (Collier 1998). Pooling of information is a two-way mechanism where the individual involved in direct interpersonal interactions gives some information and/or obtains some from others in return. Copying is a one-way mechanism that takes place by physical observation of the others' experiments without a direct interaction between agents. In this paper we focus on information pooling through face-to-face interpersonal interactions; copying is viewed as being nested in the pooling mechanism.

By information exchange, we mean any form of information sharing among rural households, whether as recipient, provider or both. Unlike formal sources where information is transferred from providers to the consumers in a unidirectional manner, information diffusion through informal mechanisms is multidirectional. In other words, individuals simultaneously receive and provide information to each other. Although information exchange through informal means generally tends to be less costly compared to that from formal sources, it is not cost free. We attach a cost to information acquisition and provision to account for the time and effort it takes to exchange information. 
Information and knowledge about new technologies and markets have been found to diffuse through social networks of friends, relatives and acquaintances (Barr 2002; Fafchamps and Minten 2001; Collier 1998; Conley and Udry 2001). For individuals to engage in gainful information exchange, a degree of interpersonal connections between them is required (Coleman 1988; Granovetter 1973). Each individual decides on whether to participate in information exchange with others, and if so, whether to provide or acquire information, or both. Social capital accumulated in the previous period plays an important role in those decisions, by facilitating the flow of resources between agents in an economy (Putnam 1993). We assume that each agent participates in information exchange with a fixed (predetermined) level of social capital and examine how endowments of social capital influence information exchange, paying close attention to gender differences.

\section{Modeling household participation in information exchange}

The theoretical model draws from the literature on information diffusion within social networks (Barr 2000; Conley and Udry 2001) and information acquisition (Feder and Slade 1984; Just et al. 2002). While Barr (2000) assumes homogeneity among members in a network who engage in reciprocal exchange of information, we consider members in a social network to be heterogeneous and argue that for some network members, information exchange can be a oneway exchange while for others it can be a two-way exchange. Agents choose the sources of information that maximize their expected utility (Just et al. 2002; Feder and Slade 1984).

Consider a village composed of $m$ households, each linked to $n$ households either directly or indirectly. The links among the households can be in the form of clubs (associations) and/or private social networks. Associations describe finite closed groups with a common interest while private networks refer to a set of bilateral links the household is directly connected to. The linkages between these households are used in the exchange of resources based on norms of reciprocity. Let information be one of those resources that households exchange among 
themselves through their links. This allows us to model the social network as exogenous to information exchange. Each household can engage in information exchange with other households it has a direct link with, whether through associations or private networks. Thus, information from other households, indirectly linked to the household, is only accessed from direct contacts through the $n$ established links.

A household can participate in information exchange as an information receiver, information provider (sender) or both. If each alternative of participation is thought of as a possible choice, the decision maker's problem is to choose from the available options the alternative that maximizes his/her expected utility of the net benefits from participation. Benefits can be derived from knowledge gained from receiving information or from expected future resources acquired from providing information, or both.

The utility of receiving information is constrained by the cost of information acquisition, which depends on the amount of information received, the number of established social links and the personal ability to acquire information. The utility of providing information is constrained by the cost of information provision, which is defined by the individual's ability to communicate their knowledge and by the size of the social network. The decision maker also faces a social norm constraint. An individual who deliberately withholds information from another member of the social network faces a punishment, the magnitude of which depends on the size of the social network. Non-participation in a network entails zero punishment, while participation is associated with some positive level of punishment when non-compliance of norms is observed. Information about the cooperation of a network member is assumed to be freely available and observable by all other members in the same network. Finally, the utility obtained from both receiving and sending information is constrained by the cost of information acquisition and information provision, as well as by the punishment for deviating from a social norm. 


\section{ECONOMETRIC METHOD}

The decision maker is faced with a decision of whether to participate in information exchange and which form of participation. There are four feasible alternatives: 1) do not participate in information exchange, $j=0 ; 2)$ participate in information exchange as a net receiver, $j=1,3$ ) participate in information exchange as a net provider, $j=2$; and 4) participate in information exchange as both a receiver and a provider, $j=3$. Let $\boldsymbol{y}$ be a random variable taking on the values $\{0,1,2,3\}$ denoting the participation choice given a set of conditioning variables $\mathbf{x}$ (household and community characteristics, as well as the size of the social network). Each choice is associated with a different level of utility and decision makers will select alternatives that maximize their utility, as defined above. Changes in the elements of $\mathbf{x}$ affect the probabilities of choosing one alternative out of the set of available alternatives, $P(y=j \mid x)$ for $j=0,1,2,3$.

The multinomial logit is used to estimate the response probabilities associated with each outcome. A multinomial model is a conceptual extension of the standard univariate model to a system of equations with latent dependent variables. The utility derived from choice $j$ for each individual $i$ is depicted by:

$$
u_{j}=x_{i} \beta_{j}+\varepsilon_{j} \quad j=0,1 \ldots \ldots J
$$

where $u_{j}$ is the average utility associated with choice $j, \mathbf{x}$ is a vector of explanatory

variables, $\beta_{j}$ are coefficients to be estimated and $\varepsilon_{j}$ is a vector of stochastic terms assumed to be jointly distributed as multivariate normal (Maddala 1983). The probability of choosing alternative $h$ is the probability that utility from alternative $h$ exceeds the utility from alternative $j$ :

$$
\mathrm{P}(y=h)=\mathrm{P}\left(u_{h}>u_{j} \text { for } \text { all } j \neq h\right)
$$


Participation in information exchange is estimated for the full sample, while controlling for gender, as well as for two sub-samples (male- and female-headed households) in order to capture gender differences in the reciprocity of information exchange.

\section{DATA AND SAMPLE DESIGN}

The data are drawn from a survey of randomly selected banana-growing households in rural Uganda, conducted between December 2003 and October 2004. The sample domain was selected to represent major banana producing areas in eastern, central, and south-western Uganda. The sample was stratified according to low and high elevation (with a threshold of 1200 meters above sea level). Prior biophysical information suggests that elevation is correlated with soil fertility and the incidence and severity of pests and diseases, large sources of variation in banana productivity. Primary sampling units were defined at the sub-county level, allocated proportionately with respect to elevation strata. Rural villages were the secondary sampling units. One village was randomly selected per primary sampling unit. A total of 20 households with access to land were selected randomly in each village. The total sample comprises 400 households in 20 villages. Survey instruments were designed to elicit detailed information on social capital, information exchange and gender components of both processes.

\section{Variable definition and hypotheses Dependent variable}

We consider household heads as a representative member of each household. Hence our focus is on differences between female and male headed households in their formation of social capital and participation in information exchange. We define female-headed households as those led by women who are either widowed, never married or divorced. Household heads were asked to recall whether they had participated in information exchange six months prior to the interview. 
Responses were disaggregated according to whether the household received information from people other than household members and supplied information to non-household members. For each form of participation, the relationship of the respondent to the person(s) with whom information was exchanged was also recorded. Table 1 provides a summary of information exchange according to the form of participation and gender of the respondent.

Table 1--Forms of information exchange among rural households, by gender

\begin{tabular}{lccc}
\hline & \multicolumn{3}{c}{$\%$ of households } \\
\cline { 2 - 4 } Information exchange & $\begin{array}{c}\text { Pooled } \\
\text { sample } \\
(\mathrm{N}=352)\end{array}$ & $\begin{array}{c}\text { Male- } \\
\text { headed } \\
\text { households } \\
(\mathrm{N}=279)\end{array}$ & $\begin{array}{c}\text { Female- } \\
\text { headed } \\
\text { households } \\
(\mathrm{N}=73)\end{array}$ \\
\hline Not participate at all & 21.11 & 14.70 & 32.88 \\
Receive information only & 11.06 & 12.54 & 8.22 \\
Provide information only & 6.78 & 7.53 & 6.85 \\
Both receive and provide & 61.06 & 65.23 & 52.05 \\
\hline
\end{tabular}

The majority of surveyed households (about 60 percent) simultaneously received and provided information to others. Only one fifth of the households did not participate in any form of information exchange, with the proportion being much higher for female-headed households (33 percent) than that for male-headed households (15 percent). A measure of association (Pearson's chi square, significant at 0.005 ) suggests that information exchange is higher among male-headed households than among female-headed households.

\section{Explanatory variables}

Explanatory variables and their hypothesized effects are summarized in Table 2 by gender. 
Table 2--Summary of explanatory variables and hypothesized effects, by gender

\begin{tabular}{|c|c|c|c|c|c|c|}
\hline \multirow[t]{2}{*}{ Variable } & \multirow[t]{2}{*}{ Variable description } & \multirow[t]{2}{*}{ Expected effect } & \multicolumn{2}{|c|}{ Male-headed } & \multicolumn{2}{|c|}{ Female-headed } \\
\hline & & & Mean & $\mathrm{SD}$ & Mean & SD \\
\hline Age & Years of age of the household head & - & 43.41 & 15.075 & 53.07 & 15.665 \\
\hline Education & $\begin{array}{l}\text { Years of schooling of the household } \\
\text { head }\end{array}$ & $+/-$ & 5.78 & 4.091 & 2.90 & 3.749 \\
\hline Extension & $\begin{array}{l}\text { Number of contacts with extension } \\
\text { agents within a village in the year prior } \\
\text { the date of interview }\end{array}$ & $+/-$ & 2.03 & 4.993 & 1.13 & 2.206 \\
\hline Distance & Farm location from paved roads in $(\mathrm{km})$ & $+/-$ & 10.91 & 7.076 & 8.93 & 6.958 \\
\hline Elevation & $\begin{array}{l}\text { Elevation at which the farm is located } \\
(1=\text { high; } 0=\text { low })\end{array}$ & - & 0.27 & 0.444 & 0.26 & 0.442 \\
\hline \multicolumn{7}{|c|}{ Social capital variables } \\
\hline Social network & $\begin{array}{l}\text { Number of people the household closely } \\
\text { talks to and can approach in case of a } \\
\text { problem }\end{array}$ & + & 25.55 & 19.371 & 18.29 & 15.056 \\
\hline Weak ties & $\begin{array}{l}\text { Number people residing outside the sub } \\
\text { county the household head gave money } \\
\text { to or any other material goods during } \\
\text { the year prior to data of interview }\end{array}$ & + & 0.52 & 2.187 & 0.20 & 0.844 \\
\hline Civic engagement & $\begin{array}{l}\text { An index of the frequency of reading } \\
\text { newspaper, listening to radios and } \\
\text { watching television for household head }\end{array}$ & + & 8.53 & 2.725 & 6.78 & 3.181 \\
\hline
\end{tabular}


Table 2--Summary of explanatory variables and hypothesized effects, by gender (continued)

Number associations Number of associations a household belongs to

Social institutions
An index of the number of times the household participates in market places, festivals, drinking clubs, school open days, village activities, and attends prayers in a year.
$+$

21.42

$+$
1.378
1.389

16.604 
Participation in information exchange is expected to be determined by personal characteristics, social capital, and the overall production environment. Education is expected to influence information exchange both directly and indirectly. However, the direction of the effect cannot be established a priori. Education enhances the individual's ability to recognize, acquire and process information (Schultz 1975). Ability to express one's self also improves with education. Education may also increase participation in associations (Haddad and Maluccio 2003) or in other forms of social capital (i.e. civic engagement and/or the size of private social network). However, education also increases the likelihood of acquiring information from formal sources, and it can lower the likelihood of relying on informal mechanisms of information exchange.

The age of the household head is also hypothesized to influence the probability of participating in information exchange. The sign of the effect is, however, ambiguous. Age is inversely related with labor productivity, reducing incentives for information search. Age, however, is positively related with experience, or accumulated human capital, which is often derived from long-standing interactions with others.

Gender is hypothesized to indirectly influence how the individual participates in the information exchange but a direct effect can also be present. Female-headed compared to maleheaded households are likely to be disadvantaged in their access to social capital that facilitates information flow. Because women have a high opportunity cost of time, they may derive less incentive from information giving. Generally, female-headed households are expected to participate less in information exchange.

The level of extension activity in the village is used as a measure of the formal institutional factors in the individual's production environment. The variable is computed as the average number of contacts with extension agents within a village. The role of the formal information institutions is not clear. When formal information providers are less accessible, as is 
the case in most developing economies, the cost of acquiring information from them becomes high. This high cost of information acquisition implies that formal mechanisms will be substituted with informal mechanisms. However, absence of formal information institutions may imply that the rate at which new information flows into the community is low. Without new information, the community may remain in equilibrium with common knowledge as the existing knowledge. Since there is no incentive for individuals to search for common knowledge, information exchange will be minimal.

The characteristics of the production environment, such as risk factors, also determine the source of information (Just et al. 2002). A more risky production environment is likely to favor consumption of information from other farmers who may have experienced similar situations. We use elevation as a proxy for risk. Banana farmers in low elevation areas are more susceptible to pests and diseases than farmers in highland areas.

Social capital enables informal mechanisms of information exchange (Isham 2000; Narayan 1997). Social capital is measured by five indicators, each capturing a different aspect of social interaction: the size of the social network, the frequency of interaction in social institutions and civic engagement. The forms of participation in social institutions, namely, places of worship, festivals, market, drinking clubs, village meeting, and school days, were combined into an index of social institutions by summing up the individual frequencies. Likewise, an index for civic engagement was computed by summing up variables used to represent civic engagement (e.g. reading newspapers, listening to radio, watching television).

Geographical distance is commonly used as a measure of spatial diffusion of physical technologies such as seed. Following Granovetter (1973), networks formed within the same village or same sub county were classified as strong ties because the frequency of interaction is likely to be higher in geographically close networks and lower in geographically distant networks ("weak ties" (Rogers 1983)) irrespective of social relationship characterizing the network. The 
index for "weak ties" was defined as the number of people the household interacted with in the year prior to the interview that reside outside the sub-county.

The size of the household social network is depicted by 1) the total number of nonhousehold members the household can talk to closely and/or approach in case of a problem, and 2) the number of associations the household belongs to. These two types of social networks were included in the analysis separately.

All forms of social capital are hypothesized to increase the probability of information exchange. The extent to which an agent acquires external knowledge from its social network depends on the existence of the external knowledge in the network, the intensity of social interactions and the willingness to share information (Yli-Renko et al. 2002). Search for knowledge is preceded by problem awareness and this awareness can be created passively during social interactions (Rogers 1983). By encouraging awareness of the problem, social capital contributes to information exchange by stimulating the process of information search.

We also expect that social norms underlying the social networks enhance the trust and cooperation of network members, which in turn influence the proportion of individual stock of knowledge exchanged with network members. Increased trust and cooperation reduce the uncertainty about other people's willingness to reciprocate and hence enables individuals with valuable information to share it with others because they expect the reward in terms of future reciprocity (either in the form of information, cooperation or material gains) to be high.

\section{RESULTS}

\section{Gender and social capital in the context of Uganda}

In Uganda, geographical distance constitutes an important factor in shaping individual interactions and consequent information exchange. Most of the network ties among rural 
households are formed within the administrative level of a sub-county. Male-headed households tend to build and maintain larger network ties with relatives and friends than female-headed households (Table 3).

Table 3--Social capital indicators, by gender

\begin{tabular}{|c|c|c|c|}
\hline & $\begin{array}{c}\text { All } \\
\text { households } \\
(\mathrm{N}=349)\end{array}$ & $\begin{array}{c}\text { Male-headed } \\
\text { households } \\
\mathrm{N}=279\end{array}$ & $\begin{array}{c}\text { Female-headed } \\
\text { households } \\
(\mathrm{N}=73)\end{array}$ \\
\hline \multicolumn{4}{|l|}{ Social network } \\
\hline $\begin{array}{l}\text { Number of relatives in household social network } \\
\text { within sub-county }\end{array}$ & 9.2 & $9.9^{* *}$ & $6.7 * *$ \\
\hline $\begin{array}{l}\text { Number of friends in household social network within } \\
\text { sub-county }\end{array}$ & 14.9 & $15.7 *$ & $11.8^{*}$ \\
\hline Number of associations a household belongs to & 1.511 & 1.561 & 1.307 \\
\hline \multicolumn{4}{|l|}{ Weak ties } \\
\hline $\begin{array}{l}\text { Number of relatives in household social network } \\
\text { residing outside the sub county }\end{array}$ & 1.4 & 1.5 & 0.9 \\
\hline $\begin{array}{l}\text { Number of the friends in household social network } \\
\text { residing outside the sub county }\end{array}$ & 0.6 & 0.5 & 0.2 \\
\hline \multicolumn{4}{|l|}{ Civic engagement } \\
\hline Number of times household head reads a newspaper & 6.7 & $7.5^{* *}$ & $4.5^{* *}$ \\
\hline Number of times household head listens to the radio & 4.4 & 4.5 & 4.1 \\
\hline $\begin{array}{l}\text { Number of times household head listens to an } \\
\text { agricultural program on the radio }\end{array}$ & 2.8 & 3.0 & 2.2 \\
\hline Number of times household head watches television & 1.3 & 1.4 & 1.1 \\
\hline \multicolumn{4}{|c|}{ Frequency of household participation in social institutions in a year } \\
\hline Weddings/celebrations & 3.0 & 2.3 & 2.3 \\
\hline Places of worship (churches, mosques) & 37.5 & 38.1 & 39.1 \\
\hline Market places & 19.5 & $21.4 * *$ & $13.2 * *$ \\
\hline Drinking places & 56.7 & $63.5^{* *}$ & $36.5^{* *}$ \\
\hline School open days & 3.3 & 3.7 & 2.2 \\
\hline General village meetings or bulungi bwansi & 1.1 & 1.4 & 0.4 \\
\hline
\end{tabular}


The difference in the size of the social network can be attributed to the differences in the structure of the household. Females who head households are generally older and less educated and the household has less wealth assets than male-headed households. Old age, low education and poverty tend to discourage a household from accumulating social capital (Haddad and Maluccio 2003; LaFerrara 2002; Alesina and LaFerrara 2002; Godquin and Quisumbing 2006).

While male-headed households build and maintain bigger social networks with relatives and friends in close proximity than female-headed households, no differences were observed in the case of the "weak ties" form of social capital. The transaction cost of information exchange beyond the sub-county level is high for both men and women. No significant differences were found in terms of civic engagement, with the exception of reading newspapers, which men appear to do more than women. Maluccio et al. (2003) observed a similar pattern in South Africa.

Social institutions and the underlying social norms within a village influence the extent to which rural households interact and hence the rate at which information is exchanged. Six social institutions were identified in the context of rural Uganda, where households meet and interact: places of worship, market place, weddings or other related celebrations, school open days, village meetings. Places of worship are the most common social institutions in rural areas for both men and women. As a forum for the exchange of goods, markets are organized weekly, biweekly or monthly and constitute an important place where agricultural information is exchanged. Unlike places of worship, gender differences exist in the frequency of market participation. Men go to markets more often (at a rate of 21 times a year) than women. Gender differences were also observed regarding participation in drinking clubs. In rural areas of Uganda, gender norms restrict women from attending drinking clubs. Both men and women participate in weddings and celebrations and in school open days. Hence, no significant differences are found between male and female-headed households with respect to both types of social institutions. Village meetings, 
or bulungi bwansi, are activities held by village residents related to collective action such as providing free labor for local public goods (e.g. roads, water). Mainly men participate in them as women are exempted from community work and hence they rarely attend these meetings.

\section{Information exchange in the context of Uganda}

Three types of mechanisms are used in the dissemination of agricultural information in Ugandan villages: 1) formal sources (e.g. government extension services, NGOs, and on-farm research); 2) informal sources (e.g. relatives, friends, other farmers); and 3) mass media. The dissemination of new agricultural technologies in Uganda was traditionally the role of the government extension service, which was joined by several NGOs in the 1990s as part of an economic recovery program implemented in 1986. On-farm research and mass media are relatively new mechanisms introduced recently in response to a change in approach from traditional top down to farmer-to-farmer model of agricultural development in Uganda.

Although the scope of formal sources may be wide, the rate of contact with extension educators, estimated at about two times a year, is too low to be effective in circumstances when agriculture is knowledge intensive. Among banana growing farmers, about 35 percent do not have a direct contact with formal sources while 56 percent access information from both farmers and formal sources (Katungi, forthcoming). Hence informal mechanisms are the most important sources of information for farmers in Uganda.

An important aspect of informal mechanisms of information diffusion is with whom information is exchanged. The nature of the social relationships that characterize the interaction between the individuals exchanging information is presented in Table 4. Social relationships are described by the direction of information diffusion (received or sent) and are disaggregated by gender. 


\begin{tabular}{|c|c|c|c|c|c|c|}
\hline \multirow{2}{*}{$\begin{array}{l}\text { Type of } \\
\text { relationship }\end{array}$} & \multicolumn{2}{|c|}{$\begin{array}{l}\text { All households } \\
\quad(\mathrm{N}=377)\end{array}$} & \multicolumn{2}{|c|}{$\begin{array}{c}\text { Male headed } \\
\text { households }(\mathrm{N}=283)\end{array}$} & \multicolumn{2}{|c|}{$\begin{array}{c}\text { Female headed } \\
\text { households }(\mathrm{N}=73)\end{array}$} \\
\hline & Receive & Send & Receive & Send & Receive & Send \\
\hline \multicolumn{7}{|c|}{ Informal mechanisms } \\
\hline Relative & 36.34 & 40.32 & 38.52 & 43.46 & 32.88 & 32.88 \\
\hline Friend & 60.48 & 57.83 & 65.72 & 61.18 & 49.32 & 49.32 \\
\hline $\begin{array}{l}\text { Employer/ } \\
\text { employee }\end{array}$ & 4.51 & 1.86 & 5.65 & 2.12 & 1.37 & 1.37 \\
\hline Neighbor & 41.65 & 43.23 & 44.52 & 45.94 & 35.62 & 36.99 \\
\hline $\begin{array}{l}\text { Group } \\
\text { member }\end{array}$ & 21.22 & 20.16 & 22.62 & 22.26 & 16.44 & 13.70 \\
\hline \multicolumn{7}{|c|}{ Formal mechanisms } \\
\hline Extension & 7.16 & - & 7.78 & - & 4.11 & - \\
\hline Radio & 0.27 & - & 0.35 & - & 0.00 & - \\
\hline
\end{tabular}

Information networks appear to be formed around social and geographical proximity. Networks built around friendship are the most common channels of information. Local associations are an additional mechanism of information exchange for rural households. About 20 percent of the sampled households reported having exchanged information with individuals identified only as group member after accounting for friends, relatives and neighbors. This rate of information exchange facilitated by farmer groups is impressive given the fact that associations are formed by individuals who trust each others (Haddad and Maluccio 2003; Alesina and LaFerrara 2002).

\section{Estimation Results}

A multinomial model was used to study household participation in information exchange in rural Uganda. The independence of the irrelevant alternatives assumption was tested, and the null hypothesis that the odds of the outcome $j$ versus outcome $h$ are independent of other 
categories is accepted (p-values of 0.640 and 0.894 ). In terms of predicting the information exchange decisions, the model performs reasonably well (Table 5).

Table 5--Accuracy of the model's predictions

\begin{tabular}{|c|c|c|c|c|c|c|}
\hline \multirow{2}{*}{$\begin{array}{l}\text { Choice of } \\
\text { participation }\end{array}$} & \multicolumn{2}{|c|}{ Pooled sample } & \multicolumn{2}{|c|}{ Men sub sample } & \multicolumn{2}{|c|}{ Women sub sample } \\
\hline & Observed & $\begin{array}{l}\% \text { Correctly } \\
\text { predicted }\end{array}$ & Observed & $\begin{array}{l}\% \text { Correctly } \\
\text { predicted }\end{array}$ & Observed & $\begin{array}{l}\% \text { Correctly } \\
\text { predicted }\end{array}$ \\
\hline Neither & 80 & 28.75 & 42 & 33.33 & 27 & 51.85 \\
\hline $\begin{array}{l}\text { Receiver } \\
\text { only }\end{array}$ & 43 & 16.28 & 37 & 21.62 & 6 & 66.67 \\
\hline Provider only & 27 & 0 & 21 & 0 & 5 & 40 \\
\hline $\begin{array}{l}\text { Both receiver } \\
\text { and provider }\end{array}$ & 227 & 89.86 & 183 & 94.54 & 38 & 86.84 \\
\hline Total & 377 & 62.07 & 283 & 68.9 & 76 & 69.74 \\
\hline
\end{tabular}

A Chow test was also used to determine the validity of estimating two sub-samples versus using the pooled data. The null hypothesis of equal coefficients in the two groups defined by gender is rejected (F-statistic of 2.46, which exceeds the critical value at the 1 percent level), justifying the statistical validity of inferences done by sub-groups versus those for the full sample.

Marginal effects of factors that influence how male-headed and female-headed households participate in informal information exchange are computed at the mean values and are presented in Table 6. 
Table 6--Marginal effects of multinomial estimates of the choice of participation in information exchange among farmers in rural Uganda (standard errors in parentheses) ${ }^{1}$

\begin{tabular}{|c|c|c|c|c|c|c|c|c|}
\hline \multirow[b]{2}{*}{ Variable } & \multicolumn{3}{|c|}{$\begin{array}{l}\text { Pooled sample } \\
\qquad(\mathrm{N}=351)\end{array}$} & \multicolumn{3}{|c|}{$\begin{array}{l}\text { Men sub sample } \\
\quad(\mathrm{N}=280)\end{array}$} & \multicolumn{2}{|c|}{$\begin{array}{l}\text { Women sub sample } \\
\qquad(\mathrm{N}=71)\end{array}$} \\
\hline & Receive & Send & Both & Receive & Send & Both & Send & Both \\
\hline Gender $(1=$ men $)$ & $\begin{array}{l}0.079 * * \\
(0.029)\end{array}$ & $\begin{array}{c}0.001 \\
(0.034)\end{array}$ & $\begin{array}{l}-0.036 \\
(0.065)\end{array}$ & & & & & \\
\hline Elevation & $\begin{array}{l}-0.037 \\
(0.036)\end{array}$ & $\begin{array}{l}0.111^{\wedge} \\
(0.062)\end{array}$ & $\begin{array}{l}-0.110 \\
(0.079)\end{array}$ & $\begin{array}{c}-0.02514 \\
(0.042)\end{array}$ & $\begin{array}{c}0.059 \\
(0.054)\end{array}$ & $\begin{array}{l}-0.088 \\
(0.083)\end{array}$ & $\begin{array}{c}0.002 \\
(0.010)\end{array}$ & $\begin{array}{c}0.007 \\
(0.158)\end{array}$ \\
\hline Age & $\begin{array}{l}0.003 * \\
(0.001)\end{array}$ & $\begin{array}{c}0.001 \\
(0.001)\end{array}$ & $\begin{array}{c}-0.004 * * \\
(0.002)\end{array}$ & $\begin{array}{l}0.004 * * \\
(0.001)\end{array}$ & $\begin{array}{c}0.001 \\
(0.001)\end{array}$ & $\begin{array}{c}-0.005^{* *} \\
(0.002)\end{array}$ & $\begin{array}{l}1.6 \mathrm{E}-07 \\
(0.000)\end{array}$ & $\begin{array}{l}-0.001 \\
(0.004)\end{array}$ \\
\hline Education & $\begin{array}{l}-0.009 * \\
(0.005)\end{array}$ & $\begin{array}{c}0.005 \\
(0.003)\end{array}$ & $\begin{array}{c}0.004 \\
(0.007)\end{array}$ & $\begin{array}{c}-0.00814^{\wedge} \\
(0.005)\end{array}$ & $\begin{array}{c}0.005 \\
(0.003)\end{array}$ & $\begin{array}{l}-0.002 \\
(0.007)\end{array}$ & $\begin{array}{l}2.0 \mathrm{E}-06 \\
(0.0001)\end{array}$ & $\begin{array}{l}0.090^{*} \\
(0.040)\end{array}$ \\
\hline Extension & $\begin{array}{c}-0.055^{* *} \\
(0.019)\end{array}$ & $\begin{array}{c}0.010 \\
(0.015)\end{array}$ & $\begin{array}{l}0.114 * * \\
(0.030)\end{array}$ & $\begin{array}{c}-0.057 * * \\
(0.020)\end{array}$ & $\begin{array}{c}0.010 \\
(0.014)\end{array}$ & $\begin{array}{c}0.092 * * \\
(0.030)\end{array}$ & $\begin{array}{l}-1.0 \mathrm{E}-5 \\
(0.0001)\end{array}$ & $\begin{array}{l}0.254^{\wedge} \\
(0.139)\end{array}$ \\
\hline Distance & $\begin{array}{l}-0.002 \\
(0.003)\end{array}$ & $\begin{array}{c}-0.006 * * \\
(0.002)\end{array}$ & $\begin{array}{l}0.010 * * \\
(0.004)\end{array}$ & $\begin{array}{c}-0.0004 \\
(0.003)\end{array}$ & $\begin{array}{c}-0.007 * * \\
(0.003)\end{array}$ & $\begin{array}{l}0.007^{\wedge} \\
(0.004)\end{array}$ & $\begin{array}{l}5.2 \mathrm{E}-07 \\
(0.000)\end{array}$ & $\begin{array}{c}0.020 \\
(0.014)\end{array}$ \\
\hline Number of associations & $\begin{array}{l}-0.027^{\wedge} \\
(0.016)\end{array}$ & $\begin{array}{c}0.002 \\
(0.009)\end{array}$ & $\begin{array}{c}0.075 * * \\
(0.023)\end{array}$ & $\begin{array}{l}-0.024 \\
(0.018)\end{array}$ & $\begin{array}{c}0.009 \\
(0.009)\end{array}$ & $\begin{array}{l}0.059 * \\
(0.026)\end{array}$ & $\begin{array}{l}-0.00001 \\
(0.0008)\end{array}$ & $\begin{array}{l}0.154^{\wedge} \\
(0.084)\end{array}$ \\
\hline Social institutions & $\begin{array}{c}0.000 \\
(4 \mathrm{E}-04)\end{array}$ & $\begin{array}{c}0.0001 \\
(0.0001)\end{array}$ & $\begin{array}{l}0.001 * \\
(0.001)\end{array}$ & $\begin{array}{c}-0.0004 \\
(0.00010\end{array}$ & $\begin{array}{l}-9 E-05 \\
(0.000)\end{array}$ & $\begin{array}{l}0.001^{\wedge} \\
(0.001)\end{array}$ & $\begin{array}{l}2.0 \mathrm{E}-08 \\
(0.0001)\end{array}$ & $\begin{array}{c}0.004 \\
(0.003)\end{array}$ \\
\hline Civic engagement & $\begin{array}{l}-0.001 \\
(0.006)\end{array}$ & $\begin{array}{c}0.001 \\
(0.005)\end{array}$ & $\begin{array}{l}0.020 * \\
(0.010)\end{array}$ & $\begin{array}{l}-0.003 \\
(0.007)\end{array}$ & $\begin{array}{c}0.002 \\
(0.006)\end{array}$ & $\begin{array}{l}0.024 * \\
(0.011)\end{array}$ & $\begin{array}{c}-1.3 \mathrm{E}-06 \\
(0.0001)\end{array}$ & $\begin{array}{c}0.009 \\
(0.020)\end{array}$ \\
\hline Weak ties & $\begin{array}{c}0.003 \\
(0.003)\end{array}$ & $\begin{array}{c}0.000 \\
(0.002)\end{array}$ & $\begin{array}{c}0.000 \\
(0.006)\end{array}$ & $\begin{array}{c}0.003 \\
(0.003)\end{array}$ & $\begin{array}{c}0.000 \\
(0.003)\end{array}$ & $\begin{array}{c}0.000 \\
(0.006)\end{array}$ & $\begin{array}{l}4.3 \mathrm{E}-06 \\
(0.0003)\end{array}$ & $\begin{array}{c}0.039 \\
(0.042)\end{array}$ \\
\hline
\end{tabular}


Table 6--Marginal effects of multinomial estimates of the choice of participation in information exchange among farmers in rural Uganda (standard errors in parentheses) (continued)

\begin{tabular}{|c|c|c|c|c|c|c|c|c|}
\hline Social networks & $\begin{array}{c}0.000 \\
(0.001)\end{array}$ & $\begin{array}{c}0.000 \\
(0.001)\end{array}$ & $\begin{array}{c}-0.001 \\
(0.002)\end{array}$ & $\begin{array}{c}0.001 \\
(0.001)\end{array}$ & $\begin{array}{l}-1 \mathrm{E}-04 \\
(0.001)\end{array}$ & $\begin{array}{l}-0.002 \\
(0.002)\end{array}$ & $\begin{array}{c}8.0 \mathrm{E}-08 \\
(0.000)\end{array}$ & $\begin{array}{l}-0.001 \\
(0.005)\end{array}$ \\
\hline
\end{tabular}

1. These marginal effects show the effect of one unit change in the explanatory variable on the probability of choosing the participation alternative, where each alternative indicated in the column is compared with none participation alternative.

2. Estimates of the marginal effects of the probability of choosing receiver only alternative were not generated for the women sub-sample, which could be due to the small sample size.

** Significant at $1 \%, *$ significant at $5 \%$ and ${ }^{\wedge}$ significant at $10 \%$ 
The model was estimated first using the whole sample, while controlling for gender, and then using sub-samples defined by gender. In each case, the chi-square value is significant at the 1 percent, implying that the explanatory variables taken together influence the information exchange decisions.

As expected, social capital significantly influences the informal information exchange among rural households in Uganda. However it has a differential effect on the type of information exchange, with most social capital variables having a significant effect on the multidirectional exchange of information, i.e. for those who both receive and provide information from and to others. The positive association with information exchange provides support to the existing literature that social capital enhances information diffusion. In the pooled sample, gender appears to play a role only in information acquisition, with men being more likely to receive information than women. There are no significant differences between men and women in the pooled sample for information provision and for joint information provision and acquisition. However, differences in the direction of information exchange emerge across sub-samples.

Belonging to more associations appears to have a strong effect on two-way informal information exchange, increasing the likelihood that both men and women will engage in information pooling with others. The effect of associations is larger for women than for men. This could be attributed to the characteristics of associations to which women belong as compared to those of men. Qualitative information from the survey shows that female-headed households belong to associations ${ }^{4}$ that are relatively homogenous in terms of gender and religious beliefs compared to their male counterparts. The degree of homogeneity between two people communicating is believed to enhance the effectiveness of communication (Rogers 1983). Associations increase the likelihood of interacting with other people holding different pieces of information and hence the incentive for information exchange.

Higher participation in civic engagement and in social institutions also increases the probability of information exchange, with men being more likely to participate as both receivers and providers of

${ }^{4}$ Generally, female-headed households are more likely to join social associations that deal with burial, religious and cultural issues than male-headed households (Katungi, forthcoming). 
information about agriculture than women. These two forms of social capital enable decision makers to obtain new information, which could stimulate them to search for more information from others and hence catalyze the information pooling process.

The size of the private social networks and the weak ties do not seem to influence the probability of information exchange. Households with membership in a wider private social network are as likely to exchange information as people who belong to smaller social networks. However, the density of institutional social networks is an important determinant of participation in information exchange.

Personal characteristics also influence information exchange. Older men are more likely to participate as information receivers only, but less likely to engage in simultaneous receiving and providing of information, perhaps due to the low ability to communicate associated with old age. Lack of statistical significance of age among women may be associated with low variability in this sub-sample since most of the women that head households were likely to be older in age. Relatively more educated men are less likely to obtain information from others, which could be related to the ability to acquire information from formal sources among people with more formal education. The effect is different among women; more educated women are more likely to engage in two-way information sharing. This could be related to the differences in the general education attainment between gender groups. Although the education attainment of rural households is generally low, it is much lower among women.

Extension activity in the village is another important determinant of information exchange among rural households. This suggests that formal and informal sources of information exchange are complementary in the provision of different pieces of knowledge. Generally, households in villages with higher extension activity are more likely to engage in a two-way information exchange compared to households in villages with less frequent extension activity. This is true for both male- and female-headed households, though the effect is much higher for female-headed households. Thus, more frequent formal information diffusion mechanisms may stimulate the informal mechanisms of information exchange in villages in Uganda, particularly among women. 
Distance to available road infrastructure also appears to be an important factor in information exchange, though with opposing effects across the sub-samples defined by gender of household head. Households located in villages far from paved roads, with implicitly poor physical market access and communication infrastructure, are more likely to participate as both information receivers and providers, but less likely to participate in information exchange as information providers only. The transaction cost of information exchange is higher for isolated households, which stimulates a two-way exchange of information when engaging in social interactions. This is particularly true for male-headed households, as distance does not appear to have significant effect on information exchange of female-headed households.

\section{CONCLUSIONS AND POLICY IMPLICATIONS}

Established social structures, such as grassroots associations and institutions, have undoubtedly contributed to efforts of agricultural development in rural areas by improving information diffusion among farmers and transactions in the economy, thus improving efficiency of outreach programs by complementing government and market-based approaches.

This paper provides an insight into the linkages between social capital and informal information exchange among rural households in Uganda. By disaggregating the analysis by the gender of the household head, the study also provides a more detailed assessment of how differences among male and female-headed households influence information diffusion in the rural areas. Results support our initial premise that social capital significantly influences information exchange among rural households, with evidence of gender disparities in the process. Statistical analysis uncovers significant differences between male- and female-headed households in their participation in information exchange. Consistent with existing literature, female-headed households appear to engage less often in information exchange with others compared to male-headed households, a disadvantage in their access to information. Male and female-headed households also diverge in their access to different types of social capital. Male-headed households participate in civic engagement and social institutions more than female-headed households. 
They also have wider private social networks than female-headed households, but no statistical significant differences exist between male and female-headed households regarding their access to associations and "weak ties."

While social capital enhances information exchange for both male- and female-headed households, the significance and magnitude of the effect is gender specific. Local associations are more productive among female-headed households while social institutions have a higher effect among male-headed households. An important implication from this result for outreach programs is that different forms of social capital may need to be accounted for in development programs to avoid exacerbating gender inequalities in rural areas.

The results also provide support for the group based approaches in technology dissemination. Since both male and female-headed household have the same propensity to join associations, this type of social capital should be encouraged for enhanced information diffusion in the communities. Furthermore, the differences in social capital and the propensity to exchange information between men and women suggest that strategies that link the two social groups by promoting gender heterogeneous groups may have a greater impact on information diffusion.

The econometric analysis also reveals that formal extension activity in the village stimulates information exchange among rural households, particularly among women. Hence, greater support to extension programs that target farmer groups would have more impact on information diffusion in the community. Though important, articulating the relationship between road infrastructure development and information exchange requires further analysis.

Finally, the direction of information exchange is also of policy relevance. Both informal and formal mechanisms for information dissemination appear to have a significant impact on a two-way information sharing. If those more likely to receive information are also more likely to provide it, the extent of information dissemination will be larger (both in terms of geographical coverage and in terms of the 
number of farmers receiving/providing information). This warrants the support for formal extension programs as well as for community associations. 


\section{REFERENCES}

Alderman, H., J. Hoddinott, L. Haddad and C. Udry. 2003. Gender differentials in farm productivity: implications for household deficiency and agricultural policy. FCND Discussion paper No.6. Washington D.C.: International Food Policy Research Institute.

Alesina, A. and E. La Ferrara. 2002. Who trusts others? Journal of Public Economics 85: 207-234.

Barr, A. 2000. Social capital and technical information flows in the ghanaian manufacturing sector. Oxford Economic Papers, 52: 539-559

Barr, A. 2002. The functional diversity and spillover effects of social capital. Journal of African economies, 11 (1): 90-113.

Collier, P. 1998. Social capital and poverty. World Bank Social Capital Initiative Working paper No.4. Washington, D.C.: World Bank.

Conley, T. and C. Udry. 2001. Social learning through networks: the adoption of new agricultural technologies in Ghana. American Journal Agricultural Economics 83: 668-732.

Coleman, J. S., 2000. Social capital in the creation of human capital. In Social capital: A multifaceted perspective, ed. Dasgupta P. and I. Serageldin. Washington, D.C.: World Bank.

Dasgupta, P. 2005. Economics of social capital. The Economic Record, 81 (special issue): S2-S21.

Eveleens, K.G. Chisholm,R.Van de Fliert, E. Kato, M., Nhat, P.T. and Schmidt, P. (1996). Midterm review of Phase III Report. FAO Inter-country programme for the development and application of integrated pest control in rice in south and south-east Asia. P.O.Box 3700 MCPO, 1277 Makati, Metro Manilla, Philippines.

Fafchamps, M. and B. Minten. 2001. Social capital and the agricultural trade. American Journal of Agricultural Economics 83 (3): 680-685.

Fafchamps, M. and A. Quisumbing. 2003. Control and ownership of assets within rural ethiopian households. In Household decisions, gender and development. A synthesis of recent research, ed. Quisumbing, A. Washington, D.C.: International Food Policy Research Institute.

Feder, G., and R. Slade. 1984. The acquisition of information and the adoption of new technology. American Journal of Agricultural Economics 66: 312-20.

Foster, A. and M. Rosenzweig. 1995. Learning by doing and learning from others: human capital and technological change in agriculture 2. Journal of Political Economy. 103: 1176-1209. 
Godquin, M. and A. R. Quisumbing. 2006. Groups, networks and social capital in rural Philippine communities. CAPRi Working Paper \#55. Washington D.C.: International Food Policy Research Institute.

Granovetter, M.S. 1973. The strength of weak ties. The American Journal of Sociology 78 (6): 1360-1380.

Haddad, L and J.A.Maluccio. 2003. Trust, membership in groups and household welfare: Evidence from KwaZulu-Natal, South Africa. Economic Development and Cultural Change 51: 573601 .

Hiebert, D., 1974. Risk, learning and the adoption of fertilizer responsive seed varieties. American Journal of Agricultural Economics 56(4): 764-768.

Isham, J. T., 2000. A model of technology adoption with social capital. A PhD Dissertation, University of Maryland.

Ioannides, Y.M., and L.D.Loury. 2004. Information networks, neighbourhood effects and inequality. Journal of Economic Literature, XLII (December): 1056-1093.

Just, D.R., A. Steven, Wolf, Steve Wu and D. Zilberman. 2002. Consumption of economic information in agriculture. American Journal of Agriculture Economics, 84 (1): 39-52.

Katungi (forthcoming). Social capital and technology adoption on small farms: the case of banana production technology in Uganda. A PhD Dissertation, University of Pretoria, South Africa.

Kislev,Y. and N.Shchori-Bachrach, 1973. The process of an innovation cycle. American Journal of Agricultural Economics 55 (1): 28-37.

LaFerrara, E. 2002. Inequality and group participation: Theory and evidence from rural Tanzania. Journal of Public Economics 85: 235-273.

Maddala, G. 1983. Limited-dependent and qualitative variables in econometrics. Econometric Society Monographs No. 3. Cambridge University Press.

Maluccio A. J. L. Haddad and J. May. 2003. Social capital and gender in South Africa, 1993-98. In Household Decisions, Gender and Development: A synthesis of Recent Research, ed. A. Quisumbing. Washington D.C.: International Food Policy Research Institute.

Meinzen-Dick, R. and M. Zwarteveen. 2003. Gender participation in water mangement: Issues from water users associations in South Asia. In Household Decisions, Gender and Development: A synthesis of Recent Research, ed. A. Quisumbing. Washington D.C.: International Food Policy Research Institute.

Munshi, K. 2004. Social learning in a heterogeneous population: Technology Diffusion in the Indian Green revolution. Journal of Development Economics 73: 185-213. 
Narayan, D. 1997. Voices of the poor: Poverty and social capital in Tanzania. Environmentally and Sustainable Development Studies and Monographs Series, Report number 17387. Washington D.C.: World Bank.

Peters, P. 1983. Gender, development cycles and historical process: A critique of recent research on women in Botswana. Journal of Southern African Studies 10 (1): 10-122.

Putman, R. 1993. The prosperous community - social capital and public life. American Prospect, 13: $35-43$

Quisumbing, A (ed.). 2003. Household decisions, gender and development. A synthesis of recent research. Washington D.C.: International Food Policy Research Institute.

Rogers, E.M. 1983. Diffusion of innovations. New York: The Free Press.

Schultz, T. 1975. The value of the ability to deal with disequilibria. Journal of Economic Literature 13 (3): 827-846.

Wozniak, G. 1993. Joint information acquisition and new technology adoption: later versus early adoption. Review of Economic and Statistics 75: 438-445.

Yli Renko, H., E. Autio, and V. Tontti. 2002. Social capital, knowledge, and the international growth of technology-based new firms. International Business Review 1: 279-304. 


\section{List of CAPRi Working Papers}

01 Property Rights, Collective Action and Technologies for Natural Resource Management: A Conceptual Framework, by Anna Knox, Ruth Meinzen-Dick, and Peter Hazell, October 1998.

02 Assessing the Relationships between Property Rights and Technology Adoption in Smallholder Agriculture: A Review of Issues and Empirical Methods, by Frank Place and Brent Swallow, April 2000.

03 Impact of Land Tenure and Socioeconomic Factors on Mountain Terrace Maintenance in Yemen, by A. Aw-Hassan, M. Alsanabani and A. Bamatraf, July 2000 .

04 Land Tenurial Systems and the Adoption of a Mucuna Planted Fallow in the Derived Savannas of West Africa, by Victor M. Manyong and Victorin A. Houndékon, July 2000.

05 Collective Action in Space: Assessing How Collective Action Varies Across an African Landscape, by Brent M. Swallow, Justine Wangila, Woudyalew Mulatu, Onyango Okello, and Nancy McCarthy, July 2000.

06 Land Tenure and the Adoption of Agricultural Technology in Haiti, by Glenn R. Smucker, T. Anderson White, and Michael Bannister, October 2000.

07 Collective Action in Ant Control, by Helle Munk Ravnborg, Ana Milena de la Cruz, María Del Pilar Guerrero, and Olaf Westermann, October 2000.

08 CAPRi Technical Workshop on Watershed Management Institutions: A Summary Paper, by Anna Knox and Subodh Gupta, October 2000.

09 The Role of Tenure in the Management of Trees at the Community Level: Theoretical and Empirical Analyses from Uganda and Malawi, by Frank Place and Keijiro Otsuka November 2000.

10 Collective Action and the Intensification of Cattle-Feeding Techniques a Village Case Study in Kenya's Coast Province, by Kimberly Swallow, November 2000.

11 Collective Action, Property Rights, and Devolution of Natural Resource Management: Exchange of Knowledge and Implications for Policy, by Anna Knox and Ruth Meinzen-Dick, January 2001. 
12 Land Dispute Resolution in Mozambique: Evidence and Institutions of Agroforestry Technology Adoption, by John Unruh, January 2001.

13 Between Market Failure, Policy Failure, and "Community Failure": Property Rights, Crop-Livestock Conflicts and the Adoption of Sustainable Land Use Practices in the Dry Area of Sri Lanka, by Regina Birner and Hasantha Gunaweera, March 2001.

14 Land Inheritance and Schooling in Matrilineal Societies: Evidence from Sumatra, by Agnes Quisumbing and Keijuro Otsuka, May 2001.

15 Tribes, State, and Technology Adoption in Arid Land Management, Syria, by Rae, J, Arab, G., Nordblom, T., Jani, K., and Gintzburger, G., June 2001.

16 The Effects of Scales, Flows, and Filters on Property Rights and Collective Action in Watershed Management, by Brent M. Swallow, Dennis P. Garrity, and Meine van Noordwijk, July 2001.

17 Evaluating Watershed Management Projects, by John Kerr and Kimberly Chung, August 2001.

18 Rethinking Rehabilitation: Socio-Ecology of Tanks and Water Harvesting in Rajasthan, North-West India, by Tushaar Shah and K.V.Raju, September 2001.

19 User Participation in Watershed Management and Research, by Nancy Johnson, Helle Munk Ravnborg, Olaf Westermann, and Kirsten Probst, September 2001.

20 Collective Action for Water Harvesting Irrigation in the Lerman-Chapala Basin, Mexico, by Christopher A. Scott and Paul Silva-Ochoa, October 2001.

21 Land Redistribution, Tenure Insecurity, and Intensity of Production: A Study of Farm Households in Southern Ethiopia, by Stein Holden and Hailu Yohannes, October 2001.

22 Legal Pluralism and Dynamic Property Rights, by Ruth Meinzen-Dick and Rajendra Pradhan, January 2002.

23 International Conference on Policy and Institutional Options for the Management of Rangelands in Dry Areas, by Tidiane Ngaido, Nancy McCarthy, and Monica Di Gregorio, January 2002.

24 Climatic Variablity and Cooperation in Rangeland Management: A Case Study From Niger, by Nancy McCarthy and Jean-Paul Vanderlinden, September 2002. 
25 Assessing the Factors Underlying the Differences in Group Performance: Methodological Issues and Empirical Findings from the Highlands of Central Kenya, by Frank Place, Gatarwa Kariuki, Justine Wangila, Patti Kristjanson, Adolf Makauki, and Jessica Ndubi, November 2002.

26 The Importance of Social Capital in Colombian Rural Agro-Enterprises, by Nancy Johnson, Ruth Suarez, and Mark Lundy, November 2002.

27 Cooperation, Collective Action and Natural Resources Management in Burkina Faso: A Methodological Note, by Nancy McCarthy, Céline Dutilly-Diané, and Boureima Drabo, December 2002.

28 Understanding, Measuring and Utilizing Social Capital: Clarifying Concepts and Presenting a Field Application from India, by Anirudh Krishna, January 2003.

29 In Pursuit Of Comparable Concepts and Data, about Collective Action, by Amy Poteete And Elinor Ostrom, March 2003.

30 Methods of Consensus Building for Community Based Fisheries Management in Bangladesh and the Mekong Delta, by Parvin Sultana and Paul Thompson, May 2003.

31 Formal and Informal Systems in Support of Farmer Management of Agrobiodiversity: Some Policy Challenges to Consolidate Lessons Learned, by Marie Byström, March 2004.

32 What Do People Bring Into the Game: Experiments in the Field About Cooperation in the Commons, by Juan-Camilo Cárdenas and Elinor Ostrom, June 2004.

33 Methods for Studying Collective Action in Rural Development, by Ruth Meinzen-Dick, Monica Di Gregorio, and Nancy McCarthy, July 2004.

34 The Relationship between Collective Action and Intensification of Livestock Production: The Case of Northeastern Burkina Faso, by Nancy McCarthy, August 2004.

35 The Transformation of Property Rights in Kenya's Maasailand: Triggers and Motivations by Esther Mwangi, January 2005.

36 Farmers' Rights and Protection of Traditional Agricultural Knowledge, by Stephen B. Brush, January 2005. 
37 Between Conservationism, Eco-Populism and Developmentalism - Discourses in Biodiversity Policy in Thailand and Indonesia, by Heidi Wittmer and Regina Birner, January 2005.

38 Collective Action for the Conservation of On-Farm Genetic Diversity in a Center of Crop Diversity: An Assessment of the Role of Traditional Farmers' Networks, by Lone B. Badstue, Mauricio R. Bellon, Julien Berthaud, Alejandro Ramírez, Dagoberto Flores, Xóchitl Juárez, and Fabiola Ramírez, May 2005.

39 Institutional Innovations Towards Gender Equity in Agrobiodiversity Management: Collective Action in Kerala, South India,, by Martina Aruna Padmanabhan, June 2005.

40 The Voracious Appetites of Public versus Private Property: A View of Intellectual Property and Biodiversity from Legal Pluralism, by Melanie G. Wiber, July 2005.

41 Who Knows, Who Cares? Determinants of Enactment, Awareness and Compliance with Community Natural Resource Management Bylaws in Uganda, by Ephraim Nkonya, John Pender, Edward Kato, Samuel Mugarura, and James Muwonge, August 2005.

42 Localizing Demand and Supply of Environmental Services: Interactions with Property Rights, Collective Action and the Welfare of the Poor, by Brent Swallow, Ruth Meinzen-Dick, and Meine von Noordjwik, September 2005.

43 Initiatives for Rural Development through Collective Action: The Case of Household Participation in Group Activities in the Highlands of Central Kenya, By Gatarwa Kariuki and Frank Place, September 2005.

$44 \quad$ Are There Customary Rights to Plants? An Inquiry among the Baganda (Uganda), with Special Attention to Gender, by Patricia L. Howard and Gorettie Nabanoga, October 2005.

45 On Protecting Farmers' New Varieties: New Approaches to Rights on Collective Innovations in Plant Genetic Resources by Rene Salazar, Niels P. Louwaars, and Bert Visser, January 2006.

46 Subdividing the Commons: The Politics of Property Rights Transformation in Kenya's Maasailand, by Esther Mwangi, January 2006.

47 Biting the Bullet: How to Secure Access to Drylands Resources for Multiple Users, by Esther Mwangi and Stephan Dohrn, January 2006. 
48 Property Rights and the Management of Animal Genetic Resources, by Simon Anderson and Roberta Centonze, February 2006.

49 From the Conservation of Genetic Diversity to the Promotion of Quality Foodstuff: Can the French Model of 'Appellation d'Origine Contrôlée' be Exported? by Valérie Boisvert, April 2006.

50 Facilitating Collective Action and Enhancing Local Knowledge: A Herbal Medicine Case Study in Talaandig Communities, Philippines, by Herlina Hartanto and Cecil Valmores, April 2006.

51 Water, Women and Local Social Organization in the Western Kenya Highlands, by Elizabeth Were, Brent Swallow, and Jessica Roy, July 2006.

52 The Many Meanings of Collective Action: Lessons on Enhancing Gender Inclusion and Equity in Watershed Management, by Laura German, Hailemichael Taye, Sarah Charamila, Tesema Tolera, and Joseph Tanui, July 2006.

53 Decentralization and Environmental Conservation: Gender Effects from Participation in Joint Forest Management, by Arun Agrawal, Gautam Yadama, Raul Andrade, and Ajoy Bhattacharya, July 2006.

54 Improving the Effectiveness of Collective Action: Sharing Experiences from Community Forestry in Nepal, by Krishna P. Achyara and Popular Gentle, July 2006.

55 Groups, Networks, and Social Capital in the Philippine Communities, by Marie Godquin and Agnes R. Quisumbing, October 2006.

56 Collective Action in Plant Genetic Resources Management: Gendered Rules of Reputation, Trust and Reciprocity in Kerala, India, by Martina Aruna Padmanabhan, October 2006.

57 Gender and Local Floodplain Management Institutions--A case study from Bangladesh, by Parvin Sultana and Paul Thompson, October 2006.

58 Gender Differences in Mobilization for Collective Action: Case Studies of Villages in Northern Nigeria, by Saratu Abdulwahid, October 2006. 